\title{
Flavobacterium xinjiangense sp. nov. and Flavobacterium omnivorum sp. nov., novel psychrophiles from the China No. 1 glacier
}

\author{
Fei Zhu, Shan Wang and Peijin Zhou \\ Institute of Microbiology, Chinese Academy of Sciences, Beijing 100080, PR China
}

Peijin Zhou

zhou@sun.im.ac.cn

\begin{abstract}
Two novel psychrophilic bacterial strains $\left(\mathrm{ZF}-6^{\top}\right.$ and $\left.\mathrm{ZF}-8^{\top}\right)$ were isolated from the China No. 1 glacier. Polyphasic taxonomy using physiological and biochemical properties and phylogenetic analysis based on 16S rRNA gene sequences showed that the two isolates belonged to the genus Flavobacterium, and that they were distinct from each other and also from the known species of this genus. Strains $\mathrm{ZF}-6^{\top}$ and $\mathrm{ZF}-8^{\top}$ are Gram-negative and both have an optimal growth temperature of $11^{\circ} \mathrm{C}$. Strain $\mathrm{ZF}-6^{\top}$ is able to grow at $0-20^{\circ} \mathrm{C}$, the $\mathrm{G}+\mathrm{C}$ content of its genomic DNA is $34.4 \mathrm{~mol} \%$ and the major fatty acids of $Z F-6^{\top}$ are $C_{16: 1} \omega 7 c(17 \cdot 7 \%)$ and $C_{15: 1} \omega 6 c$ $(12 \cdot 7 \%)$. Strain $Z F-8^{\top}$ showed a strong ability to degrade organic macromolecules such as starch, $\mathrm{CM}$-cellulose, pectin and chitin. Its DNA G $+\mathrm{C}$ content is $35.1 \mathrm{~mol} \%$, and the major fatty acids are $\mathrm{C}_{16: 1} \omega 7 \mathrm{c}(18 \cdot 2 \%)$ and $\mathrm{C}_{15: 0}(9.9 \%)$. Phylogenetic analysis based on $16 \mathrm{~S}$ rDNA sequences indicated that $\mathrm{ZF}-6^{\top}$ and $\mathrm{ZF}-8^{\top}$ belong to the genus Flavobacterium and represent two novel species. DNA-DNA hybridization also supported the status of the two new isolates. The names Flavobacterium xinjiangense sp. nov. (type strain, $\mathrm{ZF}-6^{\top}=\mathrm{AS} 1.2749^{\top}=\mathrm{JCM} 11314^{\top}$ ) and Flavobacterium omnivorum sp. nov. (type strain, $\mathrm{ZF}-8^{\top}=\mathrm{AS} 1.2747^{\top}=\mathrm{JCM} 11313^{\top}$ ) are proposed for the two new isolates.
\end{abstract}

Cold-adapted micro-organisms are divided into two categories: obligately psychrophilic micro-organisms (psychrophiles) and facultatively psychrophilic micro-organisms (psychrotolerant organisms). A psychrophile is capable of growing at or below $0{ }^{\circ} \mathrm{C}$, but is unable to grow above $20^{\circ} \mathrm{C}$. A psychrotolerant organism, whilst capable of growth at $0{ }^{\circ} \mathrm{C}$, can grow well above $20^{\circ} \mathrm{C}$ (Morita, 1975). As $80 \%$ of the biosphere has a temperature that remains permanently below $5{ }^{\circ} \mathrm{C}$, cold-adapted micro-organisms are widely distributed in nature (Margesin \& Schinner, 1994). Most of the psychrophiles that have been characterized so far originate from the Antarctic. Psychrophiles can also be found in permanently cold environments such as fresh and marine water, polar and high alpine soils and water, glaciers and frozen or chilled foodstuffs (Margesin \& Schinner, 1994). The glacier is a relatively simple and closed ecosystem with a special biotic community, containing various psychrophilic and psychrotolerant organisms (Christner et al., 2000). In China, there are more than 46000 glaciers, with a total area of $>59000 \mathrm{~km}^{2}$. China No. 1 glacier has an area of $1.74 \mathrm{~km}^{2}$ and is located in Xinjiang province, North-West

Published online ahead of print on 1 November 2002 as DOI 10.1099/ ijs.0.02310-0.

The GenBank accession numbers of the $16 \mathrm{~S}$ rDNA sequences of ZF-6 ${ }^{\top}$ and $Z F-8^{\top}$ are AF433173 and AF433174, respectively.
China. Cold-adapted micro-organisms that inhabit these environments have not been well studied.

The genus Flavobacterium was proposed by Frankland in 1889 (Bergey et al., 1923); the description of the genus has been emended several times since then. Bernardet et al. (1996) proposed an emendment to the description, which states that the genus Flavobacterium represents predominantly gliding, pigmented bacteria and has menaquinone- 6 as the primary respiratory quinone. Species of the genus Flavobacterium have DNA G $+\mathrm{C}$ contents of 32-37 mol\%. Recently, several psychrophilic species of Flavobacterium have been reported (McCammon \& Bowman, 2000; Humphry et al., 2001). In this study, we describe two newly isolated psychrophilic bacterial strains from the China No. 1 glacier. Morphological, physiological and chemotaxonomic studies indicated that the isolates should be placed in the genus Flavobacterium. Systematic studies on 16S rDNA similarity and DNA-DNA reassociation further distinguished the two isolates from known species in the genus Flavobacterium. The names Flavobacterium xinjiangense sp. nov. and Flavobacterium omnivorum sp. nov. are proposed for these isolates.

Samples of frozen soil from the China No. 1 glacier (Xinjiang province) were collected in September 1999. Samples were stored for 2 days in an ice chest until they 
could be processed in the laboratory. The frozen soil was suspended in an equal volume of liquid PYG medium and incubated for 1-2 days at $4{ }^{\circ} \mathrm{C}$. Two millilitres of the suspension was used to inoculate PYG agar plates. The plates were incubated at $4{ }^{\circ} \mathrm{C}$ for 2 weeks. Strains ZF- $6^{\mathrm{T}}$ and ZF- $8^{\mathrm{T}}$ were obtained by selection of colonies that did not grow at $20^{\circ} \mathrm{C}$ or above. PYG medium contained $\left(\mathrm{l}^{-1}\right): 5.0 \mathrm{~g}$ polypeptone, $5.0 \mathrm{~g}$ tryptone, $10.0 \mathrm{~g}$ yeast extract, $10.0 \mathrm{~g}$ glucose and $40 \mathrm{ml}$ salt solution. The salt solution, $\mathrm{pH} 7 \cdot 2$, contained $\left(1^{-1}\right): 0.2 \mathrm{~g} \mathrm{CaCl}_{2}, 0.4 \mathrm{~g} \mathrm{MgSO}_{4} .7 \mathrm{H}_{2} \mathrm{O}, 1.0 \mathrm{~g}$ $\mathrm{K}_{2} \mathrm{HPO}_{4}, 1.0 \mathrm{~g} \mathrm{KH}_{2} \mathrm{PO}_{4}, 10.0 \mathrm{~g} \mathrm{NaHCO}$ and $2.0 \mathrm{~g} \mathrm{NaCl}$. The reference strains, Flavobacterium gillisiae ACAM $601^{\mathrm{T}}$, Flavobacterium xanthum ACAM $81^{\mathrm{T}}$, Flavobacterium columnare ATCC $23463^{\mathrm{T}}$ and Flavobacterium frigidarium ATCC $700810^{\mathrm{T}}$, were cultivated as recommended (Bernardet et al., 1996; McCammon \& Bowman, 2000; Humphry et al., 2001). The size and morphology of cells grown in PYG medium at $11^{\circ} \mathrm{C}$ for $16-24 \mathrm{~h}$ were measured and observed by transmission electron microscopy. Cells were negatively stained with $1 \%(\mathrm{w} / \mathrm{v})$ phosphotungstic acid; after airdrying, the grids were examined by using a model H-600 transmission electron microscope (Hitachi). Motility was determined by phase-contrast microscopy, using the hanging-drop technique (Skerman, 1967). For determination of gliding motility, strains were grown for 16-24 h at $11^{\circ} \mathrm{C}$ on various dilute PYG media (solidified with $1.3 \%$ agar, w/v), prepared as a thin layer on ethanol-rinsed microscope slides. Following incubation, the edges of the colonies were observed by using phase microscopy.

General physiological tests were performed as described by Smibert \& Krieg (1981). Utilization of carbon and energy sources was investigated by the use of basal medium containing $\left(1^{-1}\right)$ : $0 \cdot 1 \mathrm{~g}$ yeast extract (Oxoid), $1 \mathrm{~g}$ $\left(\mathrm{NH}_{4}\right)_{2} \mathrm{HPO}_{4}$ and $40 \mathrm{ml}$ salt solution $(\mathrm{pH} \mathrm{7 \cdot 2)}$. The medium was solidified with $1.3 \%(\mathrm{w} / \mathrm{v})$ purified agar (Oxoid). Carbon substrates were added at a concentration of $0.5 \%(\mathrm{w} / \mathrm{v})$. Testing for oxidative and fermentative acid production from carbohydrates was performed by using Leifson's medium (Leifson, 1963). Chitin hydrolysis was tested as described by Hsu \& Lockwood (1975). The detection of flexirubin-type pigments using $20 \% \mathrm{KOH}$ and of extracellular glycans using the Congo red absorption test was performed according to McCammon \& Bowman (2000). Growth temperature was determined using a TN3F temperature-gradient incubator (Advantec). For quantitative analysis of cellular fatty acids, a loop of cell mass grown on PYG agar at $11^{\circ} \mathrm{C}$ for 2 days was harvested. Fatty acid methyl esters were prepared and identified using standard methods (Stackebrandt et al., 1995), and the results were compared to the database of fatty acids in the MIDI Sherlock Microbial Identification system (Microbial ID).

Genomic DNA was extracted and purified as described by Sambrook et al. (1989). The DNA G + C content was determined by the thermal denaturation method (Sly et al., 1986) with a Shimadzu UV-1206 spectrophotometer equipped with a TB-85 thermostat. DNA-DNA hybridization was carried out as described by Tindall et al. (1984). DNA fragments were labelled with $\left[\alpha_{-}{ }^{32} \mathrm{P}\right] \mathrm{dATP}$, following the instructions provided with the Nick Translation kit (Promega). The 16S rRNA genes of strains ZF- $6^{\mathrm{T}}$ and ZF$8^{\mathrm{T}}$ were amplified by PCR using the Promega Taq kit with primers 43F and 1541R (Liu et al., 2000). Purified PCR products were ligated to the pGEM-T vector (Promega) and cloned according to the manufacturer's instructions. Sequencing reactions were carried out using the ABI PRISM BigDye Primer cycle sequencing kit, and sequencing was performed on an ABI 373S DNA sequencer (both Applied Biosystems). Almost-complete $16 \mathrm{~S}$ rDNA nucleotide sequences of $\mathrm{ZF}-6^{\mathrm{T}}$ and $\mathrm{ZF}-\mathrm{8}^{\mathrm{T}}$ were determined (1466 nt for both). The $16 \mathrm{~S}$ rDNA sequences of ZF- $6^{\mathrm{T}}$ and $\mathrm{ZF}-8^{\mathrm{T}}$ were aligned with reference sequences from GenBank by using the multiple sequence alignment program CLUSTAL W (Thompson et al., 1994). After removing non-base characters and ambiguous bases from the reference sequences, $1177 \mathrm{nt}$ was used for DNA similarity calculation and phylogenetic tree construction. Evolutionary distance matrices were calculated by using the algorithm of Jukes \& Cantor (1969) with the DNADIST program within the PHYLIP package (Felsenstein, 1993). A phylogenetic tree based on $K_{\text {nuc }}$ was constructed using the neighbour-joining method with the Kimura two-parameter model in TREECON for Windows (Van de Peer \& De Wachter, 1994).

Cells of strains ZF- $6^{\mathrm{T}}$ and ZF- ${ }^{\mathrm{T}}$ were strictly aerobic, Gramnegative and rod-shaped with rounded ends (Fig. 1). Colonies on PYG agar were circular, convex with entire margins and a smooth appearance. The optimal temperature for growth was $11^{\circ} \mathrm{C}$; growth occurred at $0{ }^{\circ} \mathrm{C}$, but not at $20^{\circ} \mathrm{C}$. Motility of the strains was not detected by phasecontrast microscopy in semi-solid medium culture. Gliding motility was not observed. The two strains were not able to grow on sea-water agar. Flexirubin pigments were absent. Colonies of $\mathrm{ZF}-6^{\mathrm{T}}$ on PYG medium were pale yellow, while those of $\mathrm{ZF}-8^{\mathrm{T}}$ were orange. The other characteristic physiological differences between $\mathrm{ZF}-6^{\mathrm{T}}$ and $\mathrm{ZF}-8^{\mathrm{T}}$ are summarized in Table 1.

Strains $\mathrm{ZF}-6^{\mathrm{T}}$ and $\mathrm{ZF}-8^{\mathrm{T}}$ possessed similar fatty acid profiles, shown in Table 2 . The most abundant fatty acid of ZF- $6^{\mathrm{T}}$ and $\mathrm{ZF}-8^{\mathrm{T}}$ was $\mathrm{C}_{16: 1} \omega 7 c$, in line with other psychrophilic Flavobacterium species (Bernadet et al., 1996; McCammon \& Bowman, 2000; Humphry et al., 2001). In addition, ZF-6 ${ }^{\mathrm{T}}$ and $\mathrm{ZF}-8^{\mathrm{T}}$ did not seem to produce $\mathrm{i}-\mathrm{C}_{17: 1} \omega 7 \mathrm{c}, \mathrm{i}-\mathrm{C}_{17: 1} \omega 5 c$

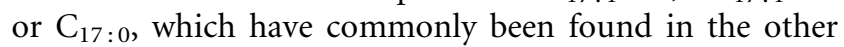
psychrophilic Flavobacterium species (fatty acids representing $<1 \%$ were not considered). There were abundant monounsaturated and branched fatty acids in the membranes of ZF- $6^{\mathrm{T}}$ and $\mathrm{ZF}-8^{\mathrm{T}}$, which is consistent with other psychrophilic Flavobacterium species. Such fatty acids contribute to the maintenance of membrane fluidity at low temperature (Russell \& Hamamoto, 1998).

Comparative studies indicated that the $16 \mathrm{~S}$ rDNA sequence of ZF-6 $6^{\mathrm{T}}$ shared $90 \cdot 5-96 \cdot 8 \%$ similarity with other Flavobacterium $16 \mathrm{~S}$ rDNA sequences, with the most similar 

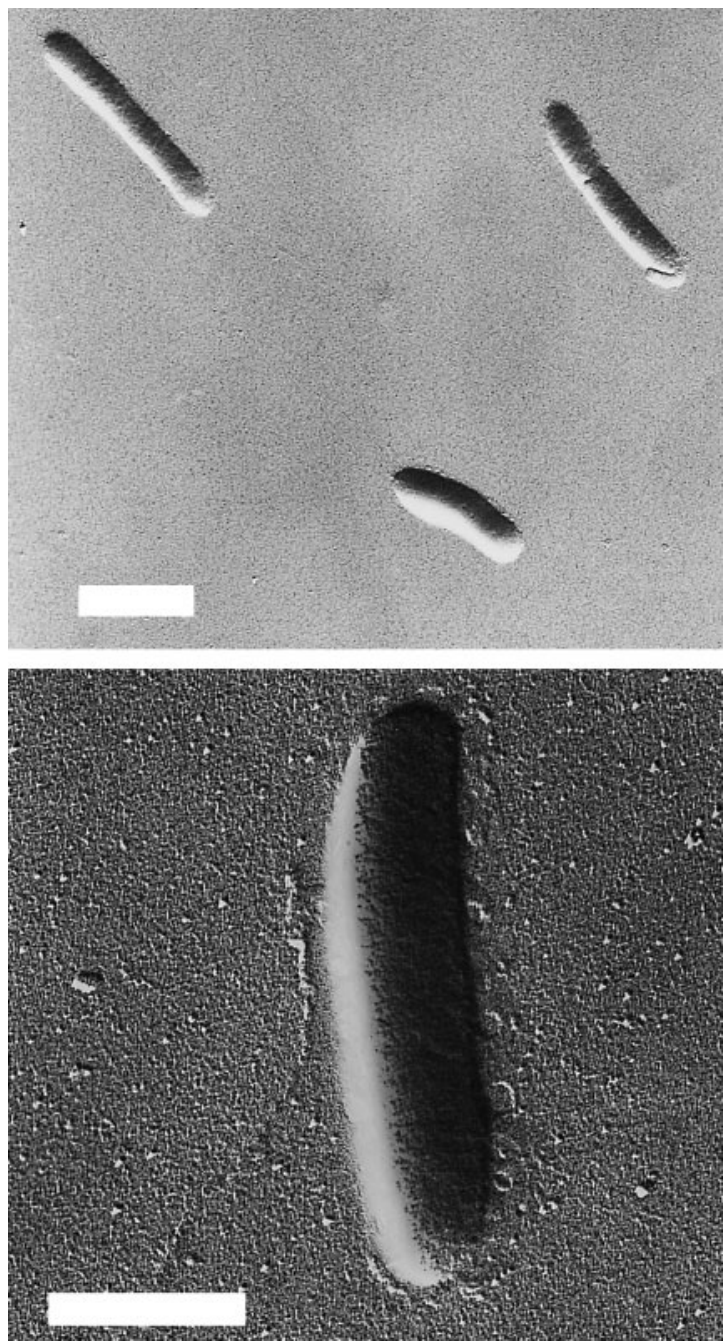

Fig. 1. Transmission electron microphotographs of $Z F-6^{\top}$ (top) and $\mathrm{ZF}-8^{\top}$ (bottom). Bars, $1 \mu \mathrm{m}$.

being that of $F$. gillisiae $(96 \cdot 8 \%)$. The $16 \mathrm{~S}$ rRNA gene sequence of $\mathrm{ZF}-8^{\mathrm{T}}$ was $92 \cdot 0-97 \cdot 3 \%$ similar to those of other Flavobacterium species, with the most similar being that of F. columnare $(97 \cdot 3 \%) . \mathrm{ZF}-6^{\mathrm{T}}$ and $\mathrm{ZF}-8^{\mathrm{T}}$ shared $96 \cdot 6 \%$ similarity with each other. The phylogenetic tree clearly indicated that $\mathrm{ZF}-6^{\mathrm{T}}$ and $\mathrm{ZF}-8^{\mathrm{T}}$ should be included in the genus Flavobacterium (Fig. 2); they formed two distinct branches within the Flavobacterium clade, which were supported by bootstrap resampling values of 69 and $56 \%$, respectively.

The DNA G $+\mathrm{C}$ contents of strains $\mathrm{ZF}-6^{\mathrm{T}}$ and $\mathrm{ZF}-8^{\mathrm{T}}$ were 34.4 and $35.1 \mathrm{~mol} \%$, respectively, which fell within the range expected for Flavobacterium species (32-37 mol\%). These data were compatible with the assignment of the strains to the genus Flavobacterium.

The high sequence similarity of the new isolates among themselves and to some other Flavobacterium species
Table 1. Characteristics that differentiate $Z F-6^{\top}$ and $Z F-8^{\top}$ from other psychrophilic Flavobacterium species

Taxa: $1, \mathrm{ZF}-6^{\mathrm{T}} ; 2, \mathrm{ZF}-8^{\mathrm{T}}$ (data for taxa $1-2$ from this study); 3 , F. gillisiae; 4, F. xanthum; 5, F. tegetincola; 6, F. psychrophilum [data for taxa 3-6 from McCammon \& Bowman (2000)]; 7, F. hibernum [data from McCammon et al. (1998)]; 8, F. frigidarium [data from Humphry et al. (2001)]. +, Positive; (+), positive, weak or delayed response; - , negative; $\mathrm{v}$, variable.

\begin{tabular}{|c|c|c|c|c|c|c|c|c|}
\hline Characteristic & 1 & 2 & 3 & 4 & 5 & 6 & 7 & 8 \\
\hline \multicolumn{9}{|l|}{ Growth on: } \\
\hline Sea-water agar & - & - & + & + & + & - & - & + \\
\hline Nutrient agar & $(+)$ & + & + & + & + & - & + & + \\
\hline Trypticase soy agar & - & + & + & + & + & - & + & + \\
\hline Growth at $20^{\circ} \mathrm{C}$ & - & - & + & + & + & - & + & + \\
\hline Gliding motility & - & - & - & - & + & $(+)$ & + & - \\
\hline Flexirubin pigment & - & - & - & - & - & + & + & - \\
\hline Glucose utilization & + & + & + & + & + & - & + & + \\
\hline Acid from carbohydrates & - & - & + & + & + & - & + & - \\
\hline \multicolumn{9}{|l|}{ Degradation of: } \\
\hline Gelatin & + & - & - & + & - & + & + & + \\
\hline Casein & + & + & + & + & - & + & + & + \\
\hline Starch & - & + & + & + & - & - & + & - \\
\hline CM-cellulose & - & + & - & - & - & - & - & - \\
\hline Pectin & - & + & - & - & - & - & - & - \\
\hline Chitin & + & + & + & - & - & - & - & - \\
\hline Aesculin & + & + & + & + & - & - & + & + \\
\hline DNA & - & - & - & - & - & $(+)$ & + & - \\
\hline Tyrosine & - & - & - & - & - & $\mathrm{V}$ & + & - \\
\hline Precipitate on egg-yolk medium & - & - & - & - & - & + & - & - \\
\hline Oxidase & + & + & - & + & - & - & + & + \\
\hline ONPG hydrolysis & - & + & - & - & - & - & + & - \\
\hline $\mathrm{H}_{2} \mathrm{~S}$ production & + & - & - & + & - & - & - & - \\
\hline Nitrate reduction & - & + & - & + & - & - & + & - \\
\hline $\mathrm{G}+\mathrm{C}$ content $(\mathrm{mol} \%)$ & 34 & 35 & 32 & 36 & 32 & 35 & 36 & 35 \\
\hline
\end{tabular}

necessitated DNA-DNA hybridization tests. The genomic DNA of ZF-6 ${ }^{\mathrm{T}}$ was $11 \cdot 4,19 \cdot 3,29 \cdot 5$ and $25 \cdot 3 \%$ similar to that of F. gillisiae ACAM $601^{\mathrm{T}}, F$. xanthum ACAM $81^{\mathrm{T}}$, F. frigidarium ATCC $700810^{\mathrm{T}}$ and $\mathrm{ZF}-8^{\mathrm{T}}$, respectively. The genomic DNA of $\mathrm{ZF}-8^{\mathrm{T}}$ was $7 \cdot 9,14 \cdot 6,21 \cdot 6,28 \cdot 2$ and $13 \cdot 6 \%$ similar to that of F. gillisiae ACAM $601^{\mathrm{T}}$, F. xanthum ACAM $81^{\mathrm{T}}, F$. columnare ATCC $23463^{\mathrm{T}}, F$. frigidarium ATCC $700810^{\mathrm{T}}$ and $\mathrm{ZF}-6^{\mathrm{T}}$, respectively. Analysis of the results indicated that DNA similarities between $\mathrm{ZF}-6^{\mathrm{T}}, \mathrm{ZF}-8^{\mathrm{T}}$ and other related Flavobacterium species were clearly below $70 \%$ (which is considered to be the threshold value for the delineation of species).

On the basis of phenotypic, genotypic and phylogenetic data, it is clear that ZF- $6^{\mathrm{T}}$ and $\mathrm{ZF}-8^{\mathrm{T}}$ are members of the genus Flavobacterium and represent two distinct and novel species, for which the names Flavobacterium xinjiangense sp. nov. and Flavobacterium omnivorum sp. nov. are proposed. The phenotypic characteristics that differentiate these species from other psychrophilic species in the genus Flavobacterium are given in Table 1. 
Table 2. Whole-cell fatty acid profiles of $Z F-6^{\top}, Z F-8^{\top}$ and related strains

Taxa: $1, \mathrm{ZF}-6^{\mathrm{T}} ; 2, \mathrm{ZF}-8^{\mathrm{T}}$ (data for taxa $1-2$ from this study); 3 , F. gillisiae; 4, F. tegetincola; 5, F. xanthum [data for taxa 3-5 from McCammon \& Bowman (2000)]; 6, F. frigidarium [data from Humphry et al. (2001)].

\begin{tabular}{|c|c|c|c|c|c|c|}
\hline Fatty acid & 1 & 2 & 3 & 4 & 5 & 6 \\
\hline $\mathrm{i}-\mathrm{C}_{13: 0}$ & & & & $0 \cdot 2$ & & \\
\hline$a-C_{13: 0}$ & & & & $0 \cdot 3$ & & \\
\hline $\mathrm{i}-\mathrm{C}_{14: 1} \omega 9 c$ & & & $0 \cdot 2$ & & & \\
\hline $\mathrm{C}_{14: 0}$ & & & $0 \cdot 4$ & $0 \cdot 5$ & $0 \cdot 4$ & $1 \cdot 6$ \\
\hline $\mathrm{i}-\mathrm{C}_{14: 0}$ & $2 \cdot 1$ & & $0 \cdot 7$ & $0 \cdot 8$ & $0 \cdot 3$ & $3 \cdot 66$ \\
\hline$C_{15: 1} \omega 6 c$ & $12 \cdot 7$ & $4 \cdot 4$ & $21 \cdot 5$ & $1 \cdot 8$ & $7 \cdot 9$ & \\
\hline $\mathrm{i}-\mathrm{C}_{15: 1} \omega 10 c$ & $4 \cdot 1$ & $5 \cdot 2$ & $5 \cdot 1$ & $8 \cdot 9$ & $7 \cdot 3$ & \\
\hline $\mathrm{a}-\mathrm{C}_{15: 1} \omega 10 c$ & & $2 \cdot 4$ & $1 \cdot 3$ & $5 \cdot 7$ & $2 \cdot 2$ & \\
\hline $\mathrm{i}-\mathrm{C}_{15: 0}$ & $11 \cdot 6$ & $8 \cdot 6$ & $5 \cdot 1$ & $8 \cdot 0$ & $10 \cdot 6$ & $8 \cdot 8$ \\
\hline$a-C_{15: 0}$ & $6 \cdot 4$ & $9 \cdot 9$ & $5 \cdot 8$ & $15 \cdot 4$ & $10 \cdot 5$ & $15 \cdot 1$ \\
\hline $\mathrm{C}_{15: 0}$ & $8 \cdot 6$ & $4 \cdot 4$ & $7 \cdot 4$ & $6 \cdot 5$ & $6 \cdot 9$ & $4 \cdot 9$ \\
\hline $\mathrm{C}_{16: 1} \omega 7 c$ & $17 \cdot 7$ & $18 \cdot 2$ & $21 \cdot 7$ & $18 \cdot 4$ & $23 \cdot 1$ & $43 \cdot 5$ \\
\hline $\mathrm{C}_{16: 1} \omega 5 c$ & & & $0 \cdot 6$ & $0 \cdot 6$ & $0 \cdot 4$ & \\
\hline $\mathrm{i}-\mathrm{C}_{16: 1} \omega 6 c$ & $2 \cdot 4$ & $5 \cdot 6$ & $3 \cdot 2$ & $3 \cdot 8$ & $0 \cdot 5$ & \\
\hline $\mathrm{i}-\mathrm{C}_{16: 0}$ & & $5 \cdot 2$ & $3 \cdot 5$ & $4 \cdot 8$ & $1 \cdot 3$ & $8 \cdot 9$ \\
\hline $\mathrm{i}-\mathrm{C}_{16: 0}$ & & & & & & $1 \cdot 6$ \\
\hline$C_{16: 0}$ & & & $2 \cdot 9$ & $1 \cdot 9$ & $2 \cdot 1$ & $3 \cdot 1$ \\
\hline $\mathrm{C}_{17: 1} \omega 6 c$ & $10 \cdot 9$ & $5 \cdot 0$ & $0 \cdot 9$ & $2 \cdot 3$ & $0 \cdot 3$ & \\
\hline $\mathrm{i}-\mathrm{C}_{17: 1} \omega 9 c$ & & $5 \cdot 9$ & & & & \\
\hline $\mathrm{i}-\mathrm{C}_{17: 1} \omega 7 c$ & & & $4 \cdot 4$ & $3 \cdot 1$ & 40 & \\
\hline $\mathrm{i}-\mathrm{C}_{17: 1} \omega 5 c$ & & & $1 \cdot 0$ & $3 \cdot 5$ & $2 \cdot 6$ & \\
\hline $\mathrm{i}-\mathrm{C}_{17: 0}$ & & & $0 \cdot 2$ & & $0 \cdot 3$ & \\
\hline $\mathrm{a}-\mathrm{C}_{17: 0}$ & & & $1 \cdot 5$ & & & \\
\hline $\mathrm{C}_{18: 0}$ & & & $0 \cdot 6$ & & & \\
\hline $\mathrm{i}-\mathrm{C}_{15: 0} 3-\mathrm{OH}$ & $6 \cdot 6$ & $7 \cdot 1$ & $10 \cdot 0$ & $5 \cdot 7$ & $13 \cdot 1$ & \\
\hline $\mathrm{a}-\mathrm{C}_{15: 0} 3-\mathrm{OH}$ & & & $0 \cdot 2$ & $1 \cdot 0$ & $0 \cdot 8$ & \\
\hline $\mathrm{C}_{15: 0} 3-\mathrm{OH}$ & $2 \cdot 2$ & & $0 \cdot 3$ & $0 \cdot 5$ & $1 \cdot 2$ & \\
\hline $\mathrm{i}-\mathrm{C}_{16: 0} 3-\mathrm{OH}$ & $5 \cdot 5$ & $8 \cdot 7$ & $0 \cdot 8$ & $2 \cdot 8$ & $2 \cdot 0$ & \\
\hline $\mathrm{a}-\mathrm{C}_{16: 0} 3-\mathrm{OH}$ & & & $0 \cdot 4$ & $0 \cdot 1$ & $0 \cdot 2$ & \\
\hline $\mathrm{C}_{16: 0} 2-\mathrm{OH}$ & & & & & & 1 \\
\hline $\mathrm{C}_{16: 0} 3-\mathrm{OH}$ & $4 \cdot 4$ & & $0 \cdot 4$ & $1 \cdot 1$ & $1 \cdot 7$ & $1 \cdot 7$ \\
\hline $\mathrm{i}-\mathrm{C}_{17: 0} 3-\mathrm{OH}$ & $4 \cdot 9$ & $9 \cdot 4$ & $0 \cdot 5$ & $3 \cdot 0$ & $0 \cdot 3$ & \\
\hline
\end{tabular}

\section{Description of Flavobacterium xinjiangense sp. nov.}

Flavobacterium xinjiangense (xin.jiang.en'se. N.L. neut. adj. xinjiangense pertaining to Xinjiang, an autonomous region in North-West China).

Gram-negative rods, $2 \cdot 5-5 \mu \mathrm{m}$ in length and $0 \cdot 8 \mu \mathrm{m}$ in width. Aerobic, psychrophilic, non-flagellated and nongliding. Colonies are pale yellow, circular and smooth with entire edges. Optimal growth occurs at $11^{\circ} \mathrm{C}$; no growth occurs at $20^{\circ} \mathrm{C}$. No growth occurs in the presence of more than $3.5 \% \mathrm{NaCl}$. Flexirubin pigments are not detected. Catalase- and oxidase-positive and strictly heteroorganotrophic. Metabolism is respiratory. $\mathrm{H}_{2} \mathrm{~S}$ is produced. Nitrate is not reduced. No precipitate is produced on egg-yolk agar.

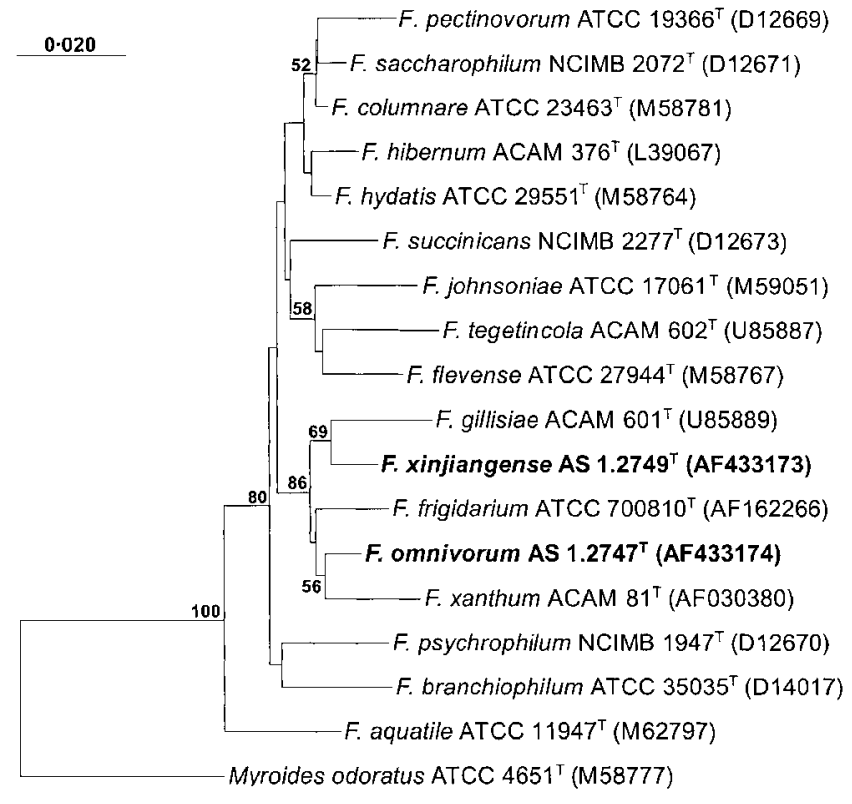

Fig. 2. Phylogenetic tree based on $16 \mathrm{~S}$ rDNA sequence divergence, showing the relationships between $Z F-6^{\top}, Z F-8^{\top}$ and related reference strains. The tree was constructed using the neighbour-joining method with the Kimura two-parameter model. Myroides odoratus was used as the outgroup sequence. Numbers at branching points represent confidence levels from 1000 bootstrap resamplings, expressed as percentages. GenBank accession numbers are given in parentheses. Bar, 0.02 $K_{\text {nuc. }}$.

The following biochemical tests are negative: arginine dihydrolase, lysine decarboxylase, ornithine decarboxylase, tryptophan deaminase, ONPG hydrolysis, indole production, Voges-Proskauer reaction and Simmons' citrate test. Peptone and casamino acids, but not sodium nitrate, ammonium chloride or L-glutamate, serve as nitrogen sources. Does not produce any acid or gas from glucose, fructose, xylose, mannitol or maltose. Degrades casein, gelatin, aesculin and chitin, but not starch, Tween 80 , agar, CM-cellulose, alginate, pectin, DNA, urea, uric acid or xanthine. The following are utilized as sole carbon sources: glucose, cellobiose, maltose, fructose, sucrose, arabinose and xylose. Sorbitol, sorbose, galactose, D-mannitol, raffinose, lactose, mannose, trehalose, glycerol, rhamnose, melibiose and inositol are not used as sole carbon sources. The major cellular fatty acids are $\mathrm{C}_{15: 1} 1 \omega 6 c(12 \cdot 7 \%), \mathrm{i}-\mathrm{C}_{15: 0}(11 \cdot 6 \%)$, $\mathrm{C}_{16: 1} \omega 7 c(17 \cdot 7 \%)$ and $\mathrm{C}_{17: 1} \omega 6 c(10 \cdot 9 \%)$. The $\mathrm{G}+\mathrm{C}$ content of the DNA of the type strain is $34 \cdot 4 \mathrm{~mol} \%$.

The type strain is $\mathrm{ZF}-6^{\mathrm{T}}\left(=\mathrm{AS} 1.2749^{\mathrm{T}}=\mathrm{JCM} 11314^{\mathrm{T}}\right)$, isolated from frozen soil from the China No. 1 glacier.

\section{Description of Flavobacterium omnivorum sp. nov.}

Flavobacterium omnivorum (om.ni.vor'um. L. n. omnis everything; L. v. vorare to devour; N.L. neut. adj. omnivorum 
eating everything, referring to the ability of the strain to degrade a wide range of macromolecules).

Gram-negative rods, $2-5 \mu \mathrm{m}$ in length and $0 \cdot 8 \mu \mathrm{m}$ in width. Aerobic, psychrophilic, non-flagellated and non-gliding. Colonies are orange, circular and smooth with entire margins. Optimal growth occurs at $11^{\circ} \mathrm{C}$; no growth occurs at $20^{\circ} \mathrm{C}$. No growth occurs in the presence of more than $3.5 \% \mathrm{NaCl}$. Flexirubin pigments are not detected. Catalaseand oxidase-positive and strictly heteroorganotrophic. Metabolism is respiratory. $\mathrm{H}_{2} \mathrm{~S}$ is not produced. Nitrate is reduced to nitrite. ONPG is hydrolysed. No precipitate is produced on egg-yolk agar. The following biochemical tests are negative: arginine dihydrolase, lysine decarboxylase, ornithine decarboxylase, tryptophan deaminase, indole production, Voges-Proskauer reaction and Simmons' citrate test. Peptone, casamino acids, sodium nitrate and ammonium chloride, but not L-glutamate, serve as nitrogen sources. Does not produce any acid or gas from glucose, fructose, xylose, mannitol or maltose. Degrades casein, aesculin, chitin, starch, alginate, CM-cellulose and pectin, but not gelatin, Tween 80, agar, DNA, urea, uric acid or xanthine. The following are utilized as sole carbon sources: glucose, cellobiose, maltose, fructose, sorbose, sucrose, lactose, rhamnose, mannose, trehalose, melibiose and arabinose. Sorbitol, galactose, D-mannitol, raffinose, glycerol, inositol and xylose are not used as sole carbon sources. The major cellular fatty acids are $\mathrm{C}_{15: 0}(9 \cdot 9 \%), \mathrm{C}_{16: 1} \omega 7 c$ $(18 \cdot 2 \%)$ and $\mathrm{i}-\mathrm{C}_{17: 0} 3-\mathrm{OH}(9 \cdot 4 \%)$. The $\mathrm{G}+\mathrm{C}$ content of the DNA of the type strain is $35 \cdot 2 \mathrm{~mol} \%$.

The type strain is $\mathrm{ZF}-8^{\mathrm{T}}\left(=\mathrm{AS} 1.2749^{\mathrm{T}}=\mathrm{JCM} 11313^{\mathrm{T}}\right)$, isolated from frozen soil from the China No. 1 glacier.

\section{Acknowledgements}

We thank Professor Shuang-Jiang Liu for his useful, critical discussion during the preparation of this manuscript.

\section{References}

Bergey, D. H., Harrison, F. C., Breed, R. S., Hammer, B. W. \& Huntoon, F. M. (1923). Genus II. Flavobacterium gen. nov. In Bergey's Manual of Determinative Bacteriology, pp. 97-117. Baltimore: Williams \& Wilkins.

Bernardet, J.-F., Segers, P., Vancanneyt, M., Berthe, F., Kersters, K. \& Vandamme, P. (1996). Cutting a Gordian knot: emended classification and description of the genus Flavobacterium, emended description of the family Flavobacteriaceae, and proposal of Flavobacterium hydatis nom. nov. (basonym, Cytophaga aquatilis Strohl and Tait 1978). Int J Syst Bacteriol 46, 128-148.

Christner, B. C., Mosley-Thompson, E., Thompson, L. G., Zagorodnov, V., Sandman, K. \& Reeve, J. N. (2000). Recovery and identification of viable bacteria immured in glacial ice. Icarus 144, 479-485.

Felsenstein, J. (1993). PHYLIP (Phylogeny Inference Package) version 3.75c. University of Washington, Seattle, USA.

Liu, H., Xu, Y., Ma, Y. \& Zhou, P. (2000). Characterization of Micrococcus antarcticus sp. nov., a psychrophilic bacterium from Antarctica. Int J Syst Evol Microbiol 50, 715-719.
Hsu, S. C. \& Lockwood, J. L. (1975). Powdered chitin agar as a selective medium for enumeration of actinomycetes in water and soil. Appl Microbiol 29, 422-426.

Humphry, D. R., George, A., Black, G. W. \& Cummings, S. P. (2001). Flavobacterium frigidarium sp. nov., an aerobic, psychrophilic, xylanolytic and laminarinolytic bacterium from Antarctica. Int J Syst Evol Microbiol 51, 1235-1243.

Jukes, T. H. \& Cantor, C. R. (1969). Evolution of protein molecules. In Mammalian Protein Metabolism, pp. 21-132. Edited by H. N. Munro. New York: Academic Press.

Leifson, E. (1963). Determination of carbohydrate metabolism of marine bacteria. J Bacteriol 85, 1183-1184.

Margesin, R. \& Schinner, F. (1994). Properties of cold-adapted microorganisms and their potential role in biotechnology. J Biotechnol 33, 1-14.

McCammon, S. A. \& Bowman, J. P. (2000). Taxonomy of Antarctic Flavobacterium species: description of Flavobacterium gillisiae sp. nov., Flavobacterium tegetincola sp. nov. and Flavobacterium xanthum sp. nov., nom. rev. and reclassification of [Flavobacterium] salegens as Salegentibacter salegens gen. nov., comb. nov. Int J Syst Evol Microbiol 50, 1055-1063.

McCammon, S. A., Innes, B. H., Bowman, J. P., Franzmann, P. D., Dobson, S. J., Holloway, P. E., Skerratt, J. H., Nichols, P. D. \& Rankin, L. M. (1998). Flavobacterium hibernum sp. nov., a lactoseutilizing bacterium from a freshwater Antarctic lake. Int $J$ Syst Bacteriol 48, 1405-1412.

Morita, R. Y. (1975). Psychrophilic bacteria. Bacteriol Rev 39, 144-167.

Russell, N. J. \& Hamamoto, T. (1998). Psychrophiles. In Extremophiles: Microbial Life in Extreme Environments, pp. 25-45. Edited by K. Horikoshi \& W. D. Grant. New York: Wiley.

Sambrook, J., Frisch, E. F. \& Maniatis, T. (1989). Molecular Cloning: a Laboratory Manual, 2nd edn. Cold Spring Harbor, NY: Cold Spring Harbor Laboratory.

Skerman, V. B. D. (1967). A Guide to the Identification of Genera of Bacteria, 3rd edn. Baltimore: Williams \& Wilkins.

Sly, L. I., Blackall, L. L., Kraat, P. C., Tian-Shen, T. \& Sangkhobol, V. (1986). The use of second derivative plots for the determination of mol\% guanine plus cytosine of DNA by the thermal denaturation method. J Microbiol Methods 5, 139-156.

Smibert, R. M. \& Krieg, N. R. (1981). Phenotypic characterization. In Manual of Methods for General Microbiology, pp. 611-654. Edited by P. Gerhardt, R. G. Murray, W. A. Wood \& N. R. Krieg. Washington, DC: American Society for Microbiology.

Stackebrandt, E., Koch, C., Gvozdiak, O. \& Schumann, P. (1995). Taxonomic dissection of the genus Micrococcus: Kocuria gen. nov., Nesterenkonia gen. nov., Kytococcus gen. nov., Dermacoccus gen. nov., and Micrococcus Cohn 1872 gen. emend. Int J Syst Bacteriol 45, 682-692.

Thompson, J. D., Higgins, D. G. \& Gibson, T. J. (1994). CLUSTAL W: improving the sensitivity of progressive multiple sequence alignment through sequence weighting, position-specific gap penalties and weight matrix choice. Nucleic Acid Res 22, 4673-4680.

Tindall, B. J., Ross, H. N. M. \& Grant, W. D. (1984). Natronobacterium gen. nov. and Natronococcus gen. nov., two new genera of haloalkaliphilic archaebacteria. Syst Appl Microbiol 5, 41-57.

Van de Peer, Y. \& De Wachter, R. (1994). TREECON for Windows: a software package for the construction and drawing of evolutionary trees for the Microsoft Windows environment. Comput Appl Biosci 10, 569-570. 